\title{
Molecular mechanisms underlying the $\alpha$-tomatine-directed apoptosis in human malignant glioblastoma cell lines A172 and U-118 MG
}

\author{
FA-ZHAO WANG, XUE-LIANG DAI and HONG-YI LIU \\ Department of Neurosurgery, The People's Hospital of Zoucheng, Zoucheng, Shandong 273500, P.R. China
}

Received March 22, 2016; Accepted March 6, 2017

DOI: $10.3892 / e t m .2017 .5294$

\begin{abstract}
In the present study, the molecular mechanisms involved in the $\alpha$-tomatine-induced apoptosis in human glioblastoma cell lines A172 and U-118 MG were investigated. Wright staining and ApopTag assays were conducted to confirm the apoptosis induced by $\alpha$-tomatine treatment. Fura- 2 assay determined an enhancement in free $\mathrm{Ca}^{2+}$ intracellularly, indicating the occurrence of $\mathrm{Ca}^{2+}$-dependent apoptosis induction. Western blot experiments were also performed to predict the apoptosis by measuring the changes in the Bax:Bcl- 2 ratio. Increase of calpain activity triggered caspase-12 expression, which in turn further activated caspase-9. In addition, an increase in the ratio of Bax:Bcl-2 accounted for the mitochondrial release of cytochrome $c$ into the cytosol for caspase-3 and caspase-9 activation. Elevated activity of calpain and caspase-3 yielded spectrin breakdown products with 145 and $120 \mathrm{kDa}$, respectively. Caspase-3 activation further cleaved the inhibitor of caspase activated DNase, while the apoptosis-inducing factor detected in the cytosol suggested that apoptosis was independent of caspase. The apoptosis induction was further supported by decreased expression levels of nuclear factor- $\kappa \mathrm{B}$ and increased expression of the inhibitor of nuclear factor, $\mathrm{I} \kappa \mathrm{B} \alpha$. In conclusion, the presented experimental results revealed the stimulation of different molecular mechanisms for $\alpha$-tomatine-mediated apoptosis in A172 and U-118 MG human glioblastoma cell lines.
\end{abstract}

\section{Introduction}

Glioblastoma is the most widespread and malignant brain tumor, and is often irremediable. This tumor has high mortality rate due to low response to the currently available treatments, resulting in short survival time that may be $<1$ year between diagnosis and mortality (1). A number of therapies are

Correspondence to: Dr Fa-Zhao Wang, Department of Neurosurgery, The People's Hospital of Zoucheng, 59 Qianquan Road, Zoucheng, Shandong 273500, P.R. China

E-mail:wangfazhao123@hotmail.com

Key words: glioblastoma, $\alpha$-tomatine, apoptosis, caspase activation available for the treatment of glioblastoma, including surgery, chemotherapy, photodynamic therapy, gene therapy, treatment with traditional Chinese medicine, radiotherapy, heat therapy and immune therapy (2-4). However, these therapies often have insufficient efficacy in curing glioblastoma due to its unusual appearance, powerful invasion and resistance towards chemotherapy. Furthermore, the administration of temozolomide, an alkylating compound, for cancer treatment in patients is limited (met with resistance) due to increased activity of the DNA repair enzyme $\mathrm{O}^{6}$-alkylguanine-DNA alkyltransferase enzyme (5). Metastatic cancer cell growth and the high resistance of cells to conventional treatments generate difficulties in complete eradication of the disease. Therefore, novel therapies are essential to defeat these limitations of conventional treatments. Furthermore, the clarification of mechanisms underlying the occurrence and development of gliomas is also essential, since it can contribute towards novel successful treatments.

In the field of cancer research, the evolution of food-derived chemopreventive compounds has been receiving increasing attention. For instance, the use of phytochemicals is an encouraging and contemporary approach for the prevention of cancer and its treatment (6). In addition, traditional herbal therapy may be considered as a favorable substitute for modern medicine (6). Previous studies have been conducted to examine the anti-invasive and antitumor properties of different herbal compounds (7). Researchers identified reduced occurrence of side effects for these herbal components when compared to chemotherapeutic agents. Prior to initiation of expensive clinical trials, in vitro evaluation and other studies can be conducted to produce easy, quick and satisfactory data (8).

Plant-based compounds have served important roles in regulating the human health and improving the quality of life for several years $(9,10)$. $\alpha$-Tomatine, isolated from Solanum plants such as Solanum lycopersicon L., is a natural steroidal glycoalkaloid found in the leaves, stems and roots of tomatoes. $\alpha$-Tomatine consists of six-ring steroidal aglycone tomatidine by which two glucose units, xylose and galactose moieties of a tetrasaccharide unit, are linked to the 3-hydroxyl group of aglycone. Different types of tomatine, such as $\beta$-tomatine, $\gamma$-tomatine and $\delta$-tomatine, are generated by the partial hydrolysis of $\alpha$-tomatine that leads to the loss of different sugar units (11). $\alpha$-Tomatine provides protection against pathogenic bacteria, fungi and viruses in plants (12). 
On evaluating the mechanistic effect of $\alpha$-tomatine, it has been proven that tomatine alters essential signaling pathways involved in the maintenance of cell proliferation, migration and differentiation $(13,14)$. Inhibition in the growth of human liver cancer HepG2 and human colon cancer HT29 cell lines was observed following in vitro $\alpha$-tomatine treatment, and the results were found to be more effective compared with those of standard anticancer drugs, such as camptothecin and doxorubicin $(15,16)$. In addition, the cytotoxicity of $\alpha$-tomatine towards various other human cancer cells has been investigated, including lung cancer (NCI-H460 and A549) $(16,17)$, prostate cancer (PC3) (18), leukemia (MOLT-4) (19), breast cancer (MCF-7) (20) and EL4 mouse lymphoma cell lines (21). Furthermore, caspase-independent cell death and apoptosis have been identified in leukemia cancer cell lines and PC3 cell lines, respectively, upon treatment with $\alpha$-tomatine; inactivation of the FAK/PI3K/AKT and ERK signaling pathways with reduced binding potential of nuclear factor $-\kappa \mathrm{B}(\mathrm{NF}-\kappa \mathrm{B})$ occurred upon inhibiting the migration and invasion of cancer cells (20).

Based on the aforementioned facts, the present study aimed to investigate the molecular mechanisms involved in the chemotherapeutic influence of $\alpha$-tomatine in two human A172 and U-118 MG glioblastoma cell lines through the induction of cell death. The current experiments strongly suggested that several mechanisms are involved in the induction of apoptosis in A172 and U-118 MG cell lines following $\alpha$-tomatine treatment.

\section{Materials and methods}

Materials. $\alpha$-Tomatine was purchased from Extrasynthese (Genay, France) and its purity was confirmed using high-performance liquid chromatography. Wright staining kit (cat. no. WS16), Fura-2 (cat. no. 47989) and trypan blue (cat. no. T6146) were obtained from Sigma-Aldrich (Merck KGaA, Darmstadt, Germany). Apop Tag assay kit (cat. no. S7100) was obtained from EMD Millipore (Billerica, MA, USA). Anti-calpain IgG antibody (cat. no. 2556; 1:1,000), all the utilized primary antibodies, as well as horseradish peroxidase conjugated goat anti-mouse (cat. no. 7076; 1:2,000) and anti-rabbit IgG (cat. no. 58802; 1:1,000) secondary antibodies, were acquired from Cell Signaling Technology, Inc. (Denver, MA, USA).

Cell culture and treatment. A172 and U-118 MG human glioblastoma cell lines were obtained from the American Type Culture Collection (Manassas, VA, USA). These cell lines were grown in RPMI-1640 medium supplemented with $10 \%$ fetal bovine serum (FBS), penicillin (1\%) and streptomycin $(100 \mu \mathrm{g} / \mathrm{ml})$ in an incubator with a humidified atmosphere of $95 \%$ air and $5 \% \mathrm{CO}_{2}$ at $37^{\circ} \mathrm{C}$. The medium was replaced every $24 \mathrm{~h}$. In all the experiments, cells were collected using trypsinization after cells were allowed to grow up to passage number 9. Prior to drug addition, cells were starved for 1 day in the same growth medium, followed by preservation using low serum state during addition of $\alpha$-tomatine. The $100 \mathrm{mM}$ $\alpha$-tomatine stock solution was prepared using dimethyl sulfoxide (DMSO) and aliquots were diluted serially using growth medium to obtain the desired concentrations for the treatment of cell lines. In order to determine the suitable $\alpha$-tomatine dose to induce apoptosis, cell viability was measured by conducting dose-dependent studies $(0-50 \mu \mathrm{M})$. It was demonstrated that 25 and $50 \mu \mathrm{M} \alpha$-tomatine were the appropriate doses for apoptosis induction, thus these were used for subsequent experiments. The control group was treated with only DMSO. The morphological and biochemical changes in cells were also analyzed to predict the apoptosis and the mechanistic pathway.

Trypan blue assay for cell viability determination. The cell viability was measured using a trypan blue assay upon treatment with $\alpha$-tomatine, as previously described (22). The cell viability was determined according to the principle that live cells do not absorb Tryphan blue due to membrane integrity, whereas cells with damaged cell membranes absorb the dye and are counted as dead cells. Viable cell counts are presented in terms of the $\%$ of the total number of cells.

Wright staining. Wright staining was performed to analyze the changes in morphological characteristics of cells in order to predict the apoptosis. Briefly, cells in the control and $\alpha$-tomatine groups were washed using phosphate-buffered saline (PBS) solution and then deposited onto slides using a Hettich centrifuge and Cytobuckets (10 min, 150 x g, room temperature; Hettich Lab Technology, Tuttlingen, Germany). Prior to monitoring the morphological changes using Wright staining, cells were fixed in ethanol (95\% v/v) (23). Subsequently, various morphological characteristics of the cells were examined, including the chromatin condensation, reduction in cell volume and presence of membrane-bound apoptotic bodies. The percentage of apoptotic cells was measured from three independent experiments.

Peroxidase in situ apoptosis assay. Apoptotic DNA fragmentation upon $\alpha$-tomatine treatment was evaluated using an ApopTag Peroxidase In Situ Apoptosis Detection kit. In brief, cells were treated with $\alpha$-tomatine as mentioned earlier, washed with PBS, centrifuged $(1,000 \times \mathrm{g}$ for $3 \mathrm{~min}$ at room temperature) and then deposited onto microscopic slides. Cells were fixed in ethanol $(95 \% \mathrm{v} / \mathrm{v})$ and then allowed to dry overnight. A protein digesting enzyme, Proteinase $\mathrm{K}$ (cat. no. 21627; EMD Millipore) was used to pretreat the cells for $10 \mathrm{~min}$ and the washed using distilled water for $\sim 3 \mathrm{~min}$. This was followed by quenching of the cells using hydrogen peroxide $(2 \% \mathrm{v} / \mathrm{v})$ for $5 \mathrm{~min}$, followed by washing twice in PBS. Next, pre-equilibrated cells were treated with TdT-enzyme and incubated for $1 \mathrm{~h}$ at $37^{\circ} \mathrm{C}$, followed by addition of stop buffer in the slide, agitation for $10 \mathrm{sec}$ and incubation at room temperature for a further $10 \mathrm{~min}$. After the reaction was stopped, the slides were washed with PBS twice and horseradish peroxidase-conjugated anti-digoxigenin antibody was added and incubated for $30 \mathrm{~min}$. Slides were removed and then washed with PBS, followed by treatment with 3,3'-diaminobenzidine at room temperature for $5 \mathrm{~min}$ and finally washing with water $\left(\mathrm{ddH}_{2} \mathrm{O}\right)$ twice. Methyl green $(0.5 \% \mathrm{v} / \mathrm{v})$ was used to counterstain the slides, which were then washed by water and n-butanol for $10 \mathrm{~min}$. Cells were dehydrated by xylene and fixed in glass coverslips. The percentage of positive apoptotic cells was then determined by counting the brown cells under a microscope $(23,24)$. 
Fura-2 assay. Alterations in intracellular calcium $\left(\left[\mathrm{Ca}^{2+}\right]_{\mathrm{i}}\right)$ in human glioblastoma cell lines (A172 and U-118 MG) were determined by Fura-2 assay, according to the reported literature $(23,24)$. In brief, cells at a density of $2 \times 10^{4}$ cells $/ \mathrm{ml}$ were grown in phenol-red medium for $72 \mathrm{~h}$, removed from the culture medium and then centrifuged to obtain pellets for $\sim 5 \mathrm{~min}$ at 2,000 rpm. Next, cells were washed twice using PBS buffer and then returned into the suspension, incubated for $2 \mathrm{~h}$ and washed twice in Locke's buffer (containing $9 \mathrm{~g}$ sodium chloride, $0.4 \mathrm{~g}$ potassium chloride, $0.1 \mathrm{~g}$ calclium chloride, $0.3 \mathrm{~g}$ sodium bicarbonate and $1 \mathrm{~g}$ glucose) which was prepared as previously described (25). Cell density was measured with a hemocytometer and then the cells were disseminated in FBS (10\%) containing Locke's buffer. Fura-2 stock solution was prepared by dissolving the appropriate amount of Fura-2 in DMSO and then diluting with FBS (10\%) containing Locke's buffer to obtain a final concentration of $2 \mu \mathrm{M}$, followed by incubation with cells for $30 \mathrm{~min}$ at $37^{\circ} \mathrm{C}$. Cells were subsequently diluted to $1 \times 10^{5}$ cells $/ \mathrm{ml}$ using Locke's buffer solution $\left(\mathrm{Ca}^{2+}\right.$ free $)$, and the $\left[\mathrm{Ca}^{2+}\right]_{\mathrm{i}}$ was determined using a previously described spectrofluorometric method (26). The fluorescence ratio was measured at wavelengths of 340 and $380 \mathrm{~nm}$ using FluoroMax (Horiba Scientific, Kyoto, Japan). Next, $200 \mu 1$ digitonin (cat. no. D141; Sigma-Aldrich; Merck KGaA) $(250 \mu \mathrm{M})$ and EDTA $(500 \mathrm{mM})$ were used to calculate the maximal and minimal ratios of $\left[\mathrm{Ca}^{2+}\right]\left(\mathrm{R}_{\max }\right.$ and $\left.\mathrm{R}_{\min }\right)$, respectively. The cell specific dissociation constants for the two cell lines were determined to be 0.378 and $0.477 \mu \mathrm{M}$, respectively, by following the manufacturer's instructions provided in the calcium calibration buffer kit (cat. no. C3008MP; Thermo Fisher Scientific, Inc., Waltham, MA, USA).

Western blotting. The adherent and suspended cells from each treatment group were collected and centrifuged at $100 \mathrm{x} \mathrm{g}$ for $10 \mathrm{~min}$ at room temperature to obtain cell pellets. The cell pellets were washed twice with PBS and resuspended in homogenized buffer solution containing Tris- $\mathrm{HCl}(50 \mathrm{mM}$, pH 7.4), EGTA (1 mM), sucrose (325 nM) and phenylmethylsulfonyl fluoride $(0.1 \mathrm{mM})$ for homogenization for $\sim 30 \mathrm{sec}$ at $4^{\circ} \mathrm{C}$. Following the homogenization process, the protein concentration in the samples was conducted using a Bradford Protein reagent (Sigma-Aldrich) and measuring spectrophotometrically the absorption at a wavelength of $595 \mathrm{~nm}$ (NanoVue spectrophotometer; GE Healthcare Life Sciences, Chicago, IL, USA).

Protein samples $(\sim 50 \mu \mathrm{g})$ were then treated with $2 \mathrm{X}$ loading buffer composed of equal amount of Tris- $\mathrm{HCl}(120 \mathrm{mM}$, pH 6.8), SDS (6\%), glycerol (20\%), 1,4-dithio-DL-threitol (200 $\mathrm{mM}), \beta$-mercaptoethanol $(10 \mathrm{mM})$ and bromophenol blue $(0.01 \%)$, and boiled for $10 \mathrm{~min}$. Gradient gels (4-20\%) were used to load the samples for electrophoresis at $200 \mathrm{~V}$ for 30 min using an electrophoretic system (GE Healthcare Life Sciences). The $\alpha$-spectrin bands were detected using electrophoresis gel (5\%) at $100 \mathrm{~V}$ for $2 \mathrm{~h}$. Subsequently, the gels were electroblotted onto nylon membranes with an electroblotting apparatus (Bio-Rad Laboratories, Inc., Hercules, CA USA). A blocking buffer solution with Tris- $\mathrm{HCl}(10 \mathrm{mM}, \mathrm{pH} 7.4)$, non-fat powdered milk (5\%) and $\mathrm{NaCl}(120 \mathrm{mM})$ was used to block the membranes and then washed with a washing buffer composed of Tris- $\mathrm{HCl}$ (10 mM, pH 7.4), $\mathrm{NaCl}(120 \mathrm{mM})$ and Tween-20
$(0.1 \%)$. Primary antibodies were then properly diluted, and added to the blots for $\sim 1 \mathrm{~h}$. Primary antibodies against the following proteins were used: Bcl-2 (cat. no. 2872; 1:1,000), cytochrome c (cat. no. 4272; 1:1,000), $\beta$-actin (cat. no. 4967; $1: 1,000$ ), calpain (cat. no. 2556; 1:1,000), caspase-12 (cat. no. $2202 ; 1: 1,000$ ), caspase-9 (cat. no. 9502; 1:1,000), caspase-3 (cat. no. 9662; 1:1,000), apoptosis-inducing factor (AIF) (cat. no. 4642, 1:1,000), Smac/Diablo (cat. no. 2954; 1:1,000), BIRC-2 (cat. no. 4952; 1:1,000), BIRC-3 (cat. no. 3130; 1:1,000), IkBa (cat. no. 9242; 1:1,000), NFkB (cat. no. 4717; 1:1,000) were purchased from Cell Signaling Technology, Inc. Primary antibody against inhibitor of caspase-activated DNase (ICAD) (cat. no. ab108521; 1:10,000) was purchased from Abcam (Cambridge, MA, USA). Primary antibodies against $145 \mathrm{kDa}$ Spectrin Breakdown Products (cat. no. CSB-EQ028022HU; 1:100) and $120 \mathrm{kDa}$ Spectrin Breakdown Products (cat. no. CSB-EQ028055HU; 1:100) were purchased from Cusabio (Hubei, China). The blots were washed thrice with washing buffer and then secondary antibodies were added for $1 \mathrm{~h}$ at a dilution of 1:2,000. Finally, the blots were then visualized with an ECL chemiluminescence system (EMD Millipore) and the optical density of bands was measured using a densitometric technique.

Statistical analysis. The acquired experimental data following $\alpha$-tomatine treatment of A172 and U-118 MG cells were analyzed using SPSS (ver 21) software (SPSS, Inc., Chicago, IL, USA). Results are presented as the mean \pm standard error of at least three independent experiments $(n \geq 3)$. The statistical differences between each group were analyzed using one-way analysis of variance followed by Tukey's honest significant difference post hoc test. $\mathrm{P}<0.05$ was considered to indicate a statistically significant difference.

\section{Results}

Cell viability and apoptosis measurements. Two different concentrations of $\alpha$-tomatine were used to determine whether it reduces cell viability and induces apoptosis in glioblastoma A172 and U-118 MG cell lines (Fig. 1). Cells were treated with different $\alpha$-tomatine concentrations (25 and $50 \mu \mathrm{M})$ and tryptan blue assay was used to determine the cell viability by measuring the absorbance under a light microscope. Treatment with $\alpha$-tomatine (25 and $50 \mu \mathrm{M}$ ) significantly reduced the cell viability in $\mathrm{A} 172$ cells to $80 \%(\mathrm{P}<0.05)$ and $65 \%(\mathrm{P}<0.01)$, respectively, whereas the viability in $\mathrm{U}-118 \mathrm{MG}$ cells was significantly reduced to $75 \%(\mathrm{P}<0.05)$ and $70 \%(\mathrm{P}<0.05)$, respectively, when compared with the control cells (Fig. 1A).

The changes in morphological characteristics due to $\alpha$-tomatine-induced apoptosis were determined using Wright staining (Fig. 1B). Wright stained cells typically exhibit characteristics including reduction of cell size, membrane blebbing or chromatin condensation as a sign of apoptotic cell death. Treatment with $\alpha$-tomatine $(25$ and $50 \mu \mathrm{M})$ in A172 cells resulted in a significant increase in apoptosis of $34 \%(\mathrm{P}<0.05)$ and $47 \%(\mathrm{P}<0.01)$, respectively, whereas an increase of $25 \%$ $(\mathrm{P}<0.05)$ and $30 \%(\mathrm{P}<0.05)$ was observed in the case of $\mathrm{U}-118$ MG cells, respectively (Fig. 1B). ApopTag assay (Fig. 1C) was further used in order to confirm the Wright staining data. In this assay, brown color stained cells were identified to be 


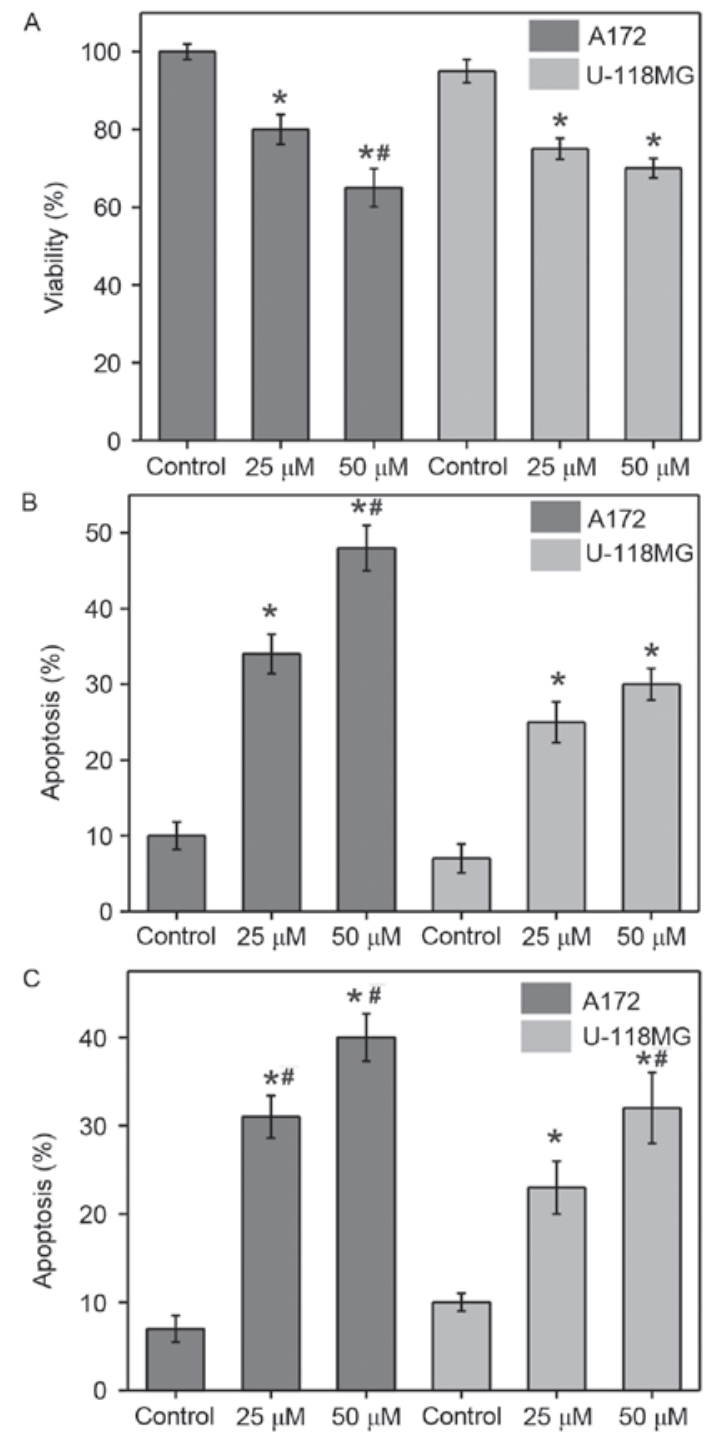

Figure 1. $\alpha$-Tomatine-treated A172 and U-118 MG demonstrated decreased cell viability and increased apoptotic features. (A) Cell viability tests were conducted using trypan blue test. (B) The apoptotic action following $\alpha$-tomatine treatment was observed by Wright staining. (C) The biochemical features of the apoptotic reaction were examined by ApopTag assay. ${ }^{*} \mathrm{P}<0.05$, ${ }^{*} \mathrm{P}<0.01$ vs. control.

apoptotic when presenting one of the morphological changes mentioned earlier. The results revealed that very few control cells exhibited brown staining, indicating a low number of positive ApopTag cells. By contrast, the $\alpha$-tomatine-treated groups exhibited marked staining and thus apoptosis, which was confirmed by the ApopTag assay and changes in the morphological characteristics. The percentage of apoptotic cells were found to be significantly increased by $33 \%(\mathrm{P}<0.01)$ and $41 \%(\mathrm{P}<0.01)$ in the A172 cell line after the treatment with 25 and $50 \mu \mathrm{M} \alpha$-tomatine, respectively, whereas apoptosis of $24 \%(\mathrm{P}<0.05)$ and $33 \%(\mathrm{P}<0.01)$ was observed in the $\mathrm{U}-118$ MG cell line, respectively (Fig. 1C).

Observation of $\left[\mathrm{Ca}^{2+}\right]_{i}$ changes upon $\alpha$-tomatine treatment. Fura-2 assay was conducted in order to monitor the $\left[\mathrm{Ca}^{2+}\right]_{i}$ changes upon $\alpha$-tomatine treatment in A172 and U-118 MG cells (Fig. 2). The results revealed that a marked increase in $\left[\mathrm{Ca}^{2+}\right]_{\mathrm{i}}$ was observed in the two cell lines upon the addition

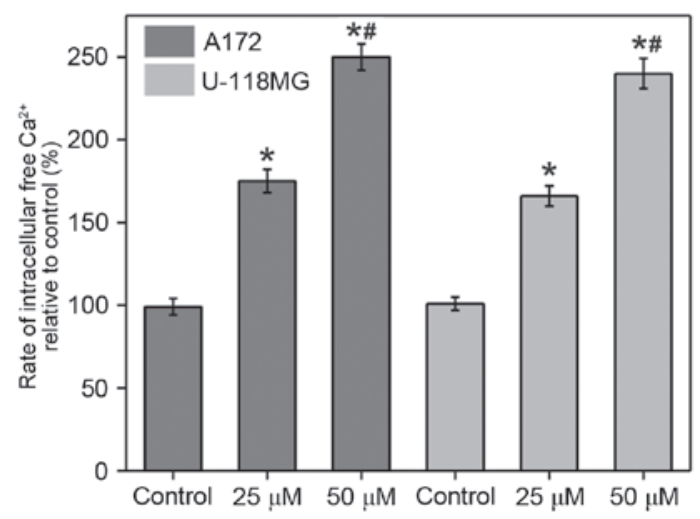

Figure 2. Measurement of intracellular free $\left[\mathrm{Ca}^{2+}\right]$ in A172 and U-118 MG cell lines following $\alpha$-tomatine treatment. ${ }^{*} \mathrm{P}<0.05,{ }^{* \#} \mathrm{P}<0.01$ vs. control.

of $\alpha$-tomatine (25 and $50 \mu \mathrm{M}$ ). The percentages of change in A172 cells were determined to be $75 \%(\mathrm{P}<0.05)$ and $150 \%$ $(\mathrm{P}<0.01)$ following treatment with 25 and $50 \mu \mathrm{M}$ of $\alpha$-tomatine, respectively, compared with the control group. In the case of U-118 MG cells, the percentages of change were found to be $66 \%(\mathrm{P}<0.05)$ and $138 \%(\mathrm{P}<0.01)$ for the treatment with 25 and $50 \mu \mathrm{M} \alpha$-tomatine, respectively (Fig. 2). In the two cell lines, treatment of $\alpha$-tomatine ( 25 and $50 \mu \mathrm{M}$ ) was observed to significantly increase the intracellular calcium levels $\left[\mathrm{Ca}^{2+}\right]_{\mathrm{i}}$ as compared with the control. These $\left[\mathrm{Ca}^{2+}\right]_{i}$ enhancements are a strong indication of apoptosis induction through endoplasmic reticulum (ER) stress and of participation of calpain in the degradation of cytosolic substrate.

Identification of $\alpha$-tomatine-induced apoptosis. It is known that the changes in the expression levels of Bcl-2 proteins are an indicator of cell apoptosis. Western blotting was conducted in the present study to measure the expression levels of Bax (pro-apoptotic) and Bcl-2 (anti-apoptotic), as well as to examine the alterations in Bax:Bcl-2 ratio (Fig. $3 \mathrm{~A}$ and $\mathrm{B}$ ). $\beta$-actin served as an internal control. It was identified that treatment with $\alpha$-tomatine resulted in an elevation in Bax expression, whereas Bcl-2 expression was reduced. The calculated ratio of Bax:Bcl-2 was significantly increased in A172 and U-118 MG cells following $\alpha$-tomatine treatment of $25(\mathrm{P}<0.05)$ and $50 \mu \mathrm{M}(\mathrm{P}<0.01)$, respectively (Fig. 3B). These alterations in the ratio of $\mathrm{Bax}: \mathrm{Bcl}-2$ upon $\alpha$-tomatine treatment indicated that the apoptosis induction was mediated through the mitochondrial pathway.

Release of mitochondrial cytochrome c. Apoptosis is initiated by various apoptotic stimuli, which result in the release of cytochrome $\mathrm{c}$ from mitochondria. This results in caspase activation through biochemical reactions, leading to cell death (20). Hence, the protein fractions of the cytosolic and mitochondrial parts in all treatment groups were separated to determine the levels of cytochrome $c$ using western blot analysis (Fig. 3A). The results demonstrated that $\alpha$-tomatine treatment in A172 and U-118 MG cell lines significantly upregulated the cytochrome $c$ protein level in the cytosolic fraction with a consequent reduction in the corresponding mitochondrial portion (Fig. 3C and D). The cytosolic cytochrome $c$ level was increased by $60 \%(\mathrm{P}<0.05)$ and $90 \%(\mathrm{P}<0.01)$ in $\mathrm{A} 172$ cells 
A
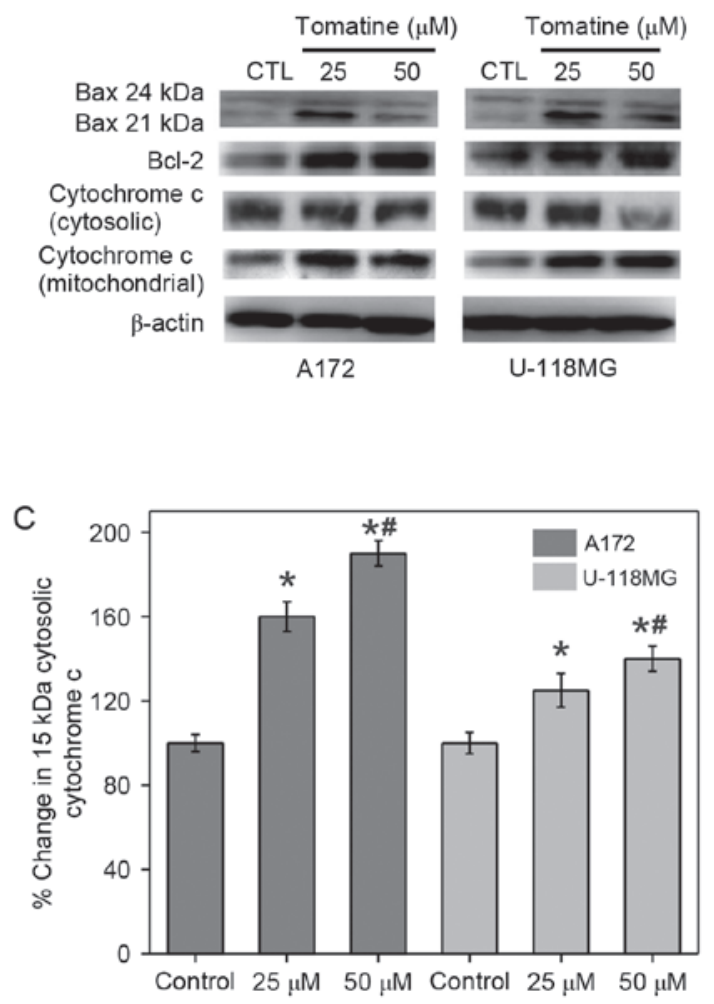
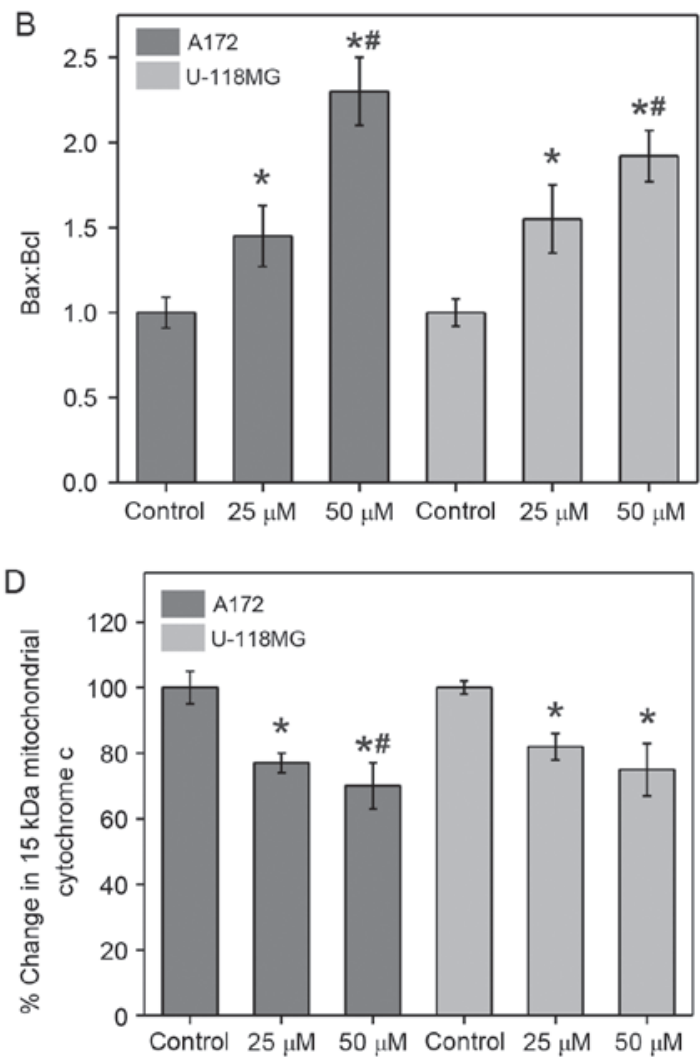

Figure 3. (A) Western blots, and quantified densitometric analysis results demonstrating the expression levels of (B) Bax:Bcl-2, (C) cytosolic cytochrome $c$ and (D) mitochondrial cytochrome $c$ in $\alpha$-tomatine-treated A172 and U-118 MG cell lines. $\mathrm{P}<0.05,{ }^{* *} \mathrm{P}<0.01 \mathrm{vs}$. control. CTL, control.

and by $25 \%(\mathrm{P}<0.05)$ and $40 \%(\mathrm{P}<0.01)$ in $\mathrm{U}-118 \mathrm{MG}$ cells following 25 and $50 \mu \mathrm{M} \alpha$-tomatine treatment, respectively (Fig. 3C). In the case of mitochondrial cytochrome $c$ levels, 25 and $50 \mu \mathrm{M} \alpha$-tomatine treatment caused a significant $22 \%$ $(\mathrm{P}<0.05)$ and $32 \%(\mathrm{P}<0.01)$ decrease in $\mathrm{A} 172$ cells, respectively, whereas the decrease in U-118 MG cells was observed to be $19 \%(\mathrm{P}<0.05)$ and $24 \%(\mathrm{P}<0.05)$, respectively (Fig. 3D). These results revealed that $\alpha$-tomatine treatment caused cytochrome $c$ release from the mitochondria into the cytosol.

Calpain expression and activation of caspases. $\alpha$-Tomatine mediated ER stress can increase $\left[\mathrm{Ca}^{2+}\right]_{\mathrm{i}}$ and trigger $\mathrm{Ca}^{2+}$-dependent calpain expression for activating caspase. Western blot experiments were performed to study the induction of calpain expression and caspase activation in A172 and U-118 MG cells upon treatment with $\alpha$-tomatine (Fig. 4A). The results indicated that treatment with 25 and $50 \mu \mathrm{M}$ $\alpha$-tomatine caused an increase in calpain protein expression of $7 \%$ (non-significant) and 36\% $(\mathrm{P}<0.01)$ in A172 respectively, and of $15 \%(\mathrm{P}<0.05)$ and $26 \%(\mathrm{P}<0.01)$ in $\mathrm{U}-118 \mathrm{MG}$ cell lines, respectively, as compared with the control (Fig. 4B). In addition, $\alpha$-tomatine (25 and $50 \mu \mathrm{M}$ ) significantly increased the protein levels of caspase-12 (40 kDa) in A172 cell lines, by $24 \%(\mathrm{P}<0.05)$ and $46 \%(\mathrm{P}<0.01)$ respectively and by $28 \%$ $(\mathrm{P}<0.05)$ and $56 \%(\mathrm{P}<0.01)$ respectively in $\mathrm{U}-118 \mathrm{MG}$ cell lines (Fig. 4C). Similarly, the protein levels of caspase-9 (35 kDa) were significantly upregulated upon administration with $\alpha$-tomatine $(25 \mu \mathrm{M}, \mathrm{P}<0.05 ; 50 \mu \mathrm{M}, \mathrm{P}<0.01)$ in $\mathrm{A} 172$ and U-118 MG cell lines (Fig. 4D). These results revealed the participation of caspase activation in the apoptosis induction.
Calpain and caspase- 3 activities. The enhancement in calpain and caspase- 3 activities from the generation of $\alpha$ II-spectrin breakdown products (SBDP) (145 and $120 \mathrm{kDa}$, respectively) were analyzed (Fig. 5A). The results indicated that the protein levels of SBDP (145 and $120 \mathrm{kDa}$ subunits) were significantly upregulated upon addition of $\alpha$-tomatine $(25 \mu \mathrm{M}$, $\mathrm{P}<0.05 ; 50 \mu \mathrm{M}, \mathrm{P}<0.01)$ in $\mathrm{A} 172$ and $\mathrm{U}-118 \mathrm{MG}$ cell lines (Fig. 5B and C). The above results are in concordance with the results of caspase-3 in A172 and U-118 MG cell lines.

Caspase-3 activation and inhibition of ICAD cleavage. The current study also investigated the activation of caspase-3 and ICAD cleavage, which is capable of translocating DNase activated by caspase to the nucleus for DNA fragmentation (Fig. 6). In A172 and U-118 MG cell lines, the protein expression of caspase- 3 fragments $(20 \mathrm{kDa})$ and ICAD (40 kDa) was significantly enhanced after treatment with $\alpha$-tomatine (25 and $50 \mu \mathrm{M})$. Treatment with 25 and $50 \mu \mathrm{M} \alpha$-tomatine resulted in an increase in the protein expression of caspase-3 fragments $(20 \mathrm{kDa})$ by $43 \%(\mathrm{P}<0.05)$ and $71 \%(\mathrm{P}<0.01)$ in $\mathrm{A} 172$ respectively, and by $10 \%$ (non-significant) and $38 \%(\mathrm{P}<0.01)$ in U-118 MG cell lines, respectively, as compared with the control (Fig. 6B). Treatment with 25 and $50 \mu \mathrm{M} \alpha$-tomatine increased the protein expression of ICAD (40 kDa) by $13 \%$ (non-significant) and $21 \%(\mathrm{P}<0.05)$ in $\mathrm{A} 172$ respectively, and by $40 \%(\mathrm{P}<0.05)$ and $48 \%(\mathrm{P}<0.01)$ in $\mathrm{U}-118 \mathrm{MG}$ cell lines, respectively, as compared with the control (Fig. 6C).

Enhancement in AIF cytosolic levels. Elevation of the permeability of the mitochondrial membrane can cause AIF release 
A

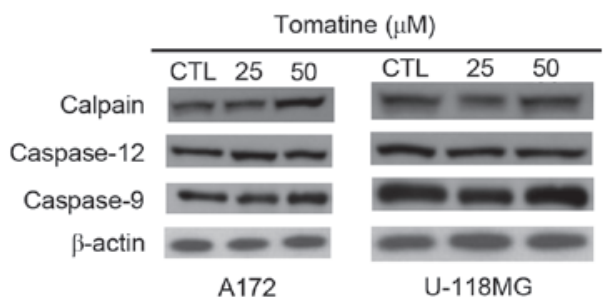

C

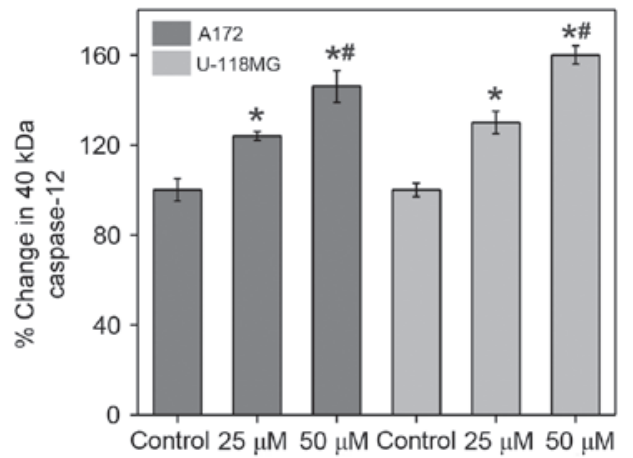

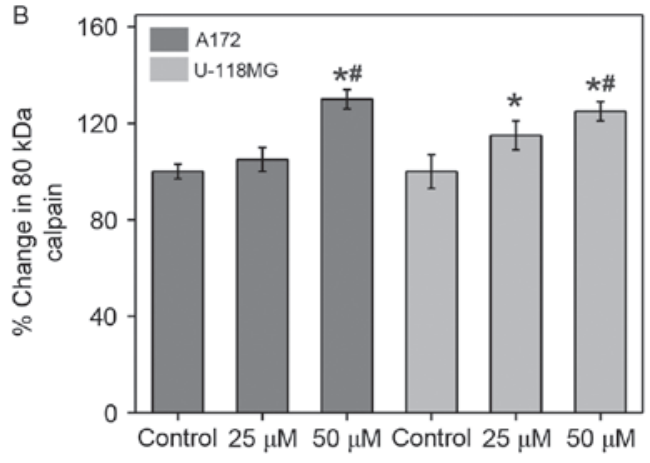

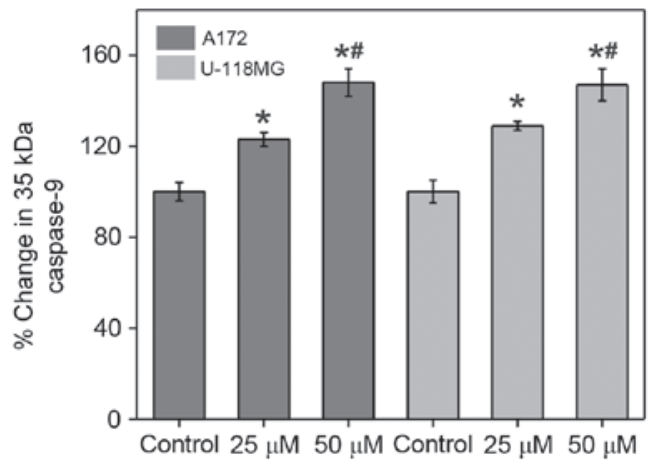

Figure 4. (A) Western blots, and quantified densitometric analysis results demonstrating the expression levels of (B) calpain, (C) caspase-12 and (D) caspase-9 in $\alpha$-tomatine-treated A172 and U-118 MG cell lines. ${ }^{*} \mathrm{P}<0.05,{ }^{* *} \mathrm{P}<0.01$ vs. control.
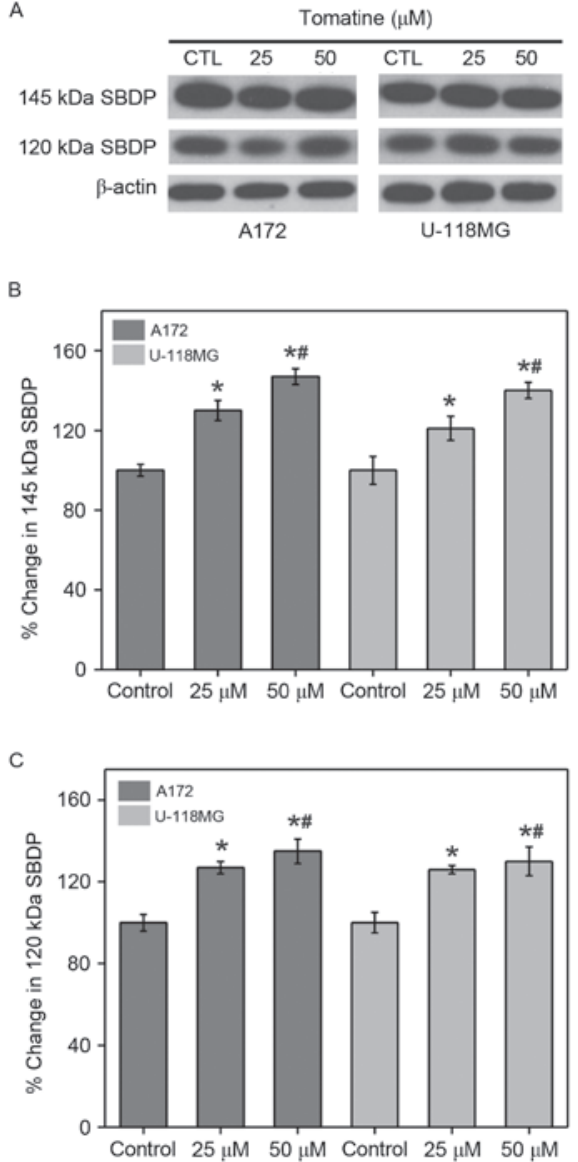

Figure 5. (A) Western blot analysis of the expression levels of SBDP in $\alpha$-tomatine-treated A172 and U-118 MG cell lines. Densitometric analysis showed the quantified expression of (B) $145 \mathrm{kDa}$ SBDP and (C) $120 \mathrm{kDa}$ SBDP. ${ }^{*} \mathrm{P}<0.05,{ }^{* \#} \mathrm{P}<0.01$ vs. control. SDBP, $\alpha$ II-spectrin breakdown products

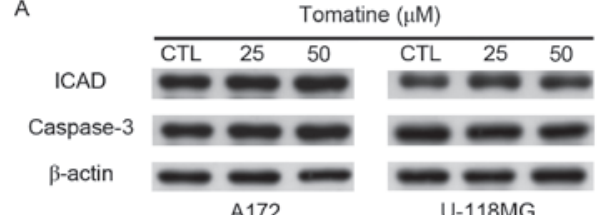

A172

$\mathrm{U}-118 \mathrm{MG}$
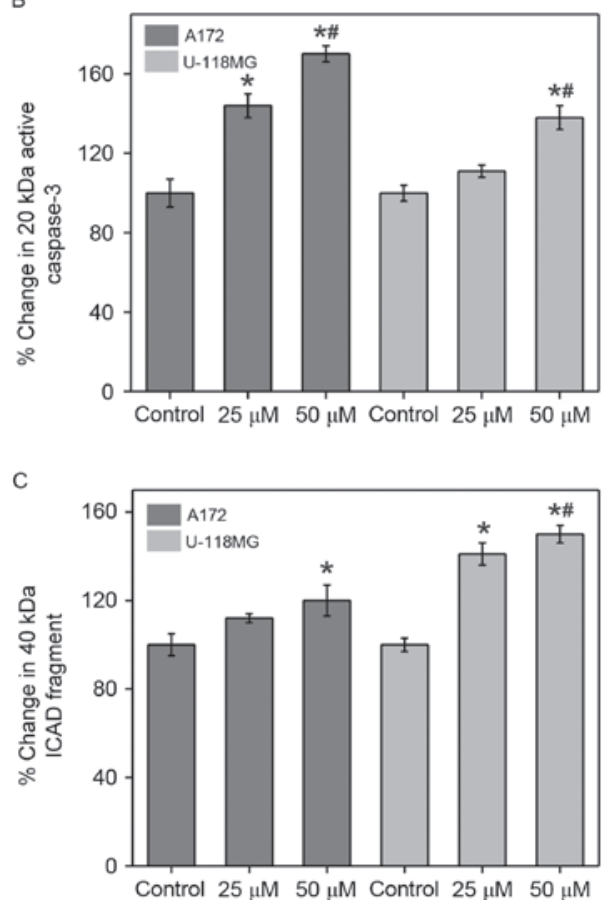

Figure 6. (A) Western blots, and quantified densitometric analysis results demonstrating the expression levels of (B) caspase-3 and (C) ICAD fragment in $\alpha$-tomatine-treated A172 and U-118 MG cell lines. ICAD, inhibitor of caspase-activated DNase. ${ }^{*} \mathrm{P}<0.05,{ }^{* \#} \mathrm{P}<0.01$ vs. control. 
into the cytoplasm. Thus, AIF levels in cytosolic fractions were determined in $\alpha$-tomatine-treated A172 and U-118 MG cells (Fig. 7). The protein expression level of AIF in the two cell lines was found to be increased by $\alpha$-tomatine treatment. Treatment with $25 \mu \mathrm{M} \alpha$-tomatine was observed to significantly increase AIF expression in A172 cells compared with control cells $(\mathrm{P}<0.05)$, whereas this increase was non-significant in $\mathrm{U}-118 \mathrm{MG}$ cells. Treatment with $50 \mu \mathrm{M} \alpha$-tomatine in the A172 and U-118 MG cell lines produced a significant increase in the cytosolic AIF levels of $60 \%(\mathrm{P}<0.01)$ and $17 \%(\mathrm{P}<0.05)$, respectively. These results suggested the involvement of a caspase-independent pathway of apoptosis.

Changes in Smac/Diablo and inhibitor of apoptosis proteins (IAPS). The release of mitochondrial Smac/Diablo proteins into the cytoplasm and the quantity of IAPs in the cytosol serve major functions in apoptosis. Therefore, the present study determined these levels with the help of western blotting experiments using $\alpha$-tomatine-treated A172 and U-118 MG cells. Treatment with $25 \mu \mathrm{M} \alpha$-tomatine resulted in a $35 \%$ $(\mathrm{P}<0.05)$ and $47 \%(\mathrm{P}<0.01)$ increase in $\mathrm{Smac} / \mathrm{Diablo}$ protein expression in A172 and U-118 MG cells, respectively (Fig. 8A and B). Also, treatment with $50 \mu \mathrm{M} \alpha$-tomatine signficantly increased the Smac/Diablo cytosolic levels in both A172 (54\%; $\mathrm{P}<0.01)$ and $\mathrm{U}-118 \mathrm{MG}(48 \%$; $\mathrm{P}<0.01)$ cells.

The current study also monitored the expression levels of two IAPs, namely c-IAP1 and c-IAP2 that are also known as Baculoviral IAP repeat-containing-2 (BIRC-2) and BIRC-3, respectively, using western blot experiments. Treatment with $25 \mu \mathrm{M} \alpha$-tomatine did not show any significant difference on BIRC-2 expression in A172 cells (7\%), while it caused a significant reduction in $\mathrm{U}-118 \mathrm{MG}$ cells $(27 \%$; $\mathrm{P}<0.05)$ as compared with the control. However, $50 \mu \mathrm{M} \alpha$-tomatine treatment significantly reduced the protein expression of BIRC-2 in $\mathrm{A} 172$ (20\%; P<0.01) and U-118 MG (29\%; P<0.01) cells as compared with control (Fig. 8C). Furthermore, treatment with $25 \mu \mathrm{M} \alpha$-tomatine significantly downregulated the protein expression of BIRC-3 in A172 (17\%; P<0.05) and U-118 MG (20\%; $\mathrm{P}<0.05)$ cell lines as compared with control. Treatment with $50 \mu \mathrm{M} \alpha$-tomatine significantly reduced the expression of BIRC-3 in A172 (37\%; P<0.01) and U-118 MG (23\%; P<0.05) cells as compared with control (Fig. 8D). These reduced expression levels of BIRC-2 and BIRC-3 are favorable for the apoptosis process.

Effect on $N F-\kappa B$ expression. Cancer cells generally increase $\mathrm{NF}-\kappa \mathrm{B}$ and reduce the inhibitor of $\mathrm{NF}-\kappa \mathrm{B}(\mathrm{I} \kappa \mathrm{B} \alpha)$ expression levels in order to promote IAP expression for cell survival. Therefore, western blotting experiments were conducted in the present study to assess the NF- $\kappa \mathrm{B}$ and $\mathrm{I} \kappa \mathrm{B} \alpha$ levels in $\mathrm{A} 172$ and U-118 MG cells (Fig. 9). Treatment with $25 \mu \mathrm{M} \alpha$-tomatine generated a significant $\sim 16 \%(\mathrm{P}<0.05)$ decrease in $\mathrm{NF}-\kappa \mathrm{B}$ expression in A172 cells, and a significant decrease of $\sim 25 \%$ $(\mathrm{P}<0.05)$ in $\mathrm{U}-118 \mathrm{MG}$ cells as compared with the control. Treatment with $50 \mu \mathrm{M} \alpha$-tomatine significantly decreased $\mathrm{NF}-\kappa \mathrm{B}$ expression in A172 ( 34\%; P<0.01) and U-118 MG $(\sim 48 \%$; $\mathrm{P}<0.01)$ cells (Fig. 9B). Furthermore, treatment with $25 \mu \mathrm{M} \alpha$-tomatine significantly increased the protein expression of $\mathrm{I} \kappa \mathrm{B} \alpha$ in $\mathrm{A} 172(26 \% ; \mathrm{P}<0.05)$, whereas no significant increase was observed in U-118 MG cells. However, $50 \mu \mathrm{M}$
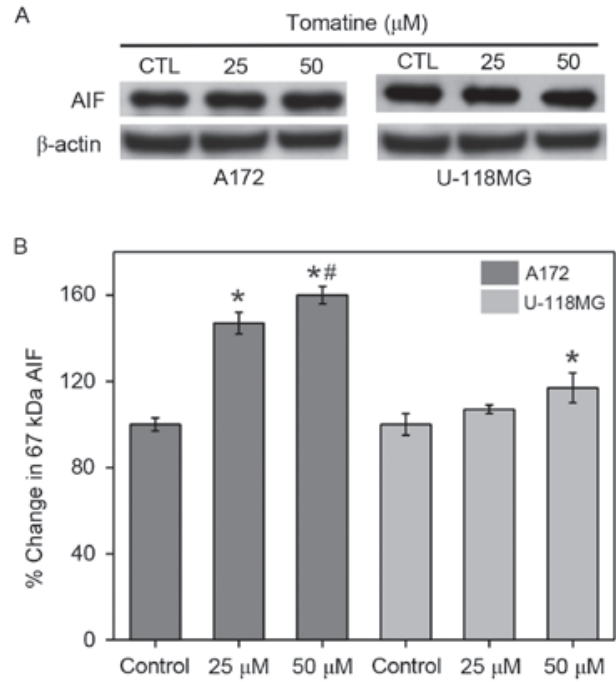

Figure 7. (A) Western blots and (B) densitometric analysis results demonstrating the change in cytosolic AIF levels following $\alpha$-tomatine treatment in A172 and U-118 MG cell lines. ${ }^{*} \mathrm{P}<0.05,{ }^{* \#} \mathrm{P}<0.01$ vs. control. AIF, apoptosis-inducing factor.

$\alpha$-tomatine treatment significantly increased $\mathrm{I} \kappa \mathrm{B} \alpha$ expression in both A172 (35\%; P<0.01) and U-118 MG (28\%; P<0.05) cell lines (Fig. 9C). These results suggest that the alterations in the expression levels of $\mathrm{NF}-\kappa \mathrm{B}$ and $\mathrm{I} \kappa \mathrm{B} \alpha$ were due to $\alpha$-tomatine-induced apoptosis.

\section{Discussion}

In the present study, $\alpha$-tomatine-induced cell death in A172 and U-118 MG human glioblastoma cell lines was reported for the first time. Based on the obtained results from these experiments, it was demonstrated that apoptosis was induced by $\alpha$-tomatine treatment and the occurrence of multiple molecular mechanisms was observed. Apoptosis was investigated by observing the morphological and biochemical characteristics of A172 and U-118 MG cells. For instance, $\alpha$-tomatine triggered an enhancement in $\left[\mathrm{Ca}^{2+}\right]$ i that can induce cell death. The obtained results revealed a connection between $\left[\mathrm{Ca}^{2+}\right] \mathrm{i}$ elevation and calpain activity in the induction of cell death. Bax and Bcl-2 levels were also examined in the cell lines, and the ratio of Bax:Bcl-2 was found to be raised following $\alpha$-tomatine treatment, which may assist in the induction of apoptosis. Overexpression of Bax is known to alter the mitochondrial membrane permeability to release cytochrome $c$, and thus the current study further investigated the changes in the cytochrome $c$ levels in both cytosolic and mitochondrial fragments. The results indicated that the cytosolic fraction levels were raised and mitochondrial levels were decreased upon $\alpha$-tomatine addition, strongly indicating the participation of mitochondrial cytochrome $c$ release in apoptosis induction.

The present study also examined the $\alpha$-tomatine-induced cell death along with caspase-9, caspase-12 and calpain activation in A172 and U-118 MG cells. The results indicated that ER stress was caused by $\alpha$-tomatine treatment for apoptosis induction in human glioblastoma cell lines. The current study results are comparable with similar apoptosis models shown by other researchers $(24,27,28)$. Earlier studies demonstrated 
A
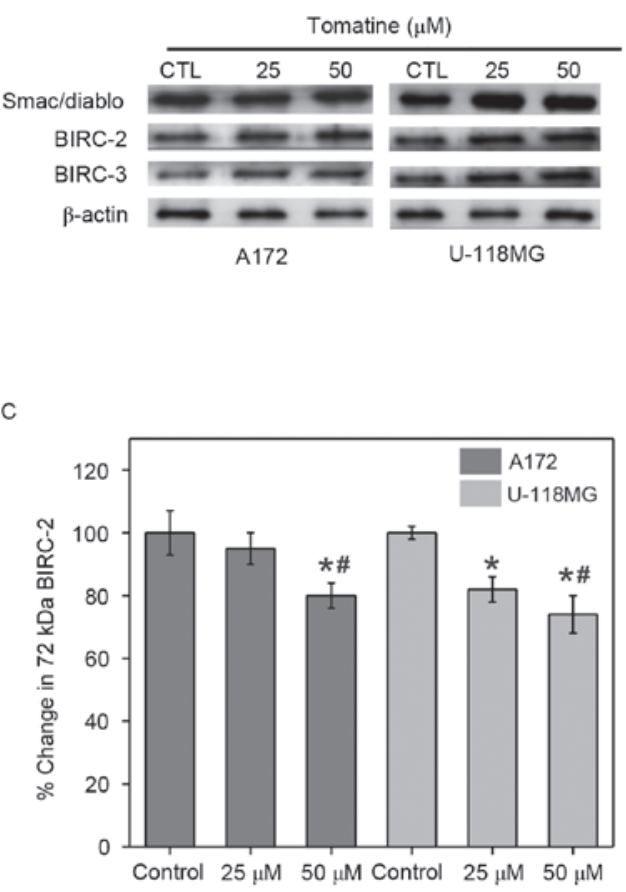

B

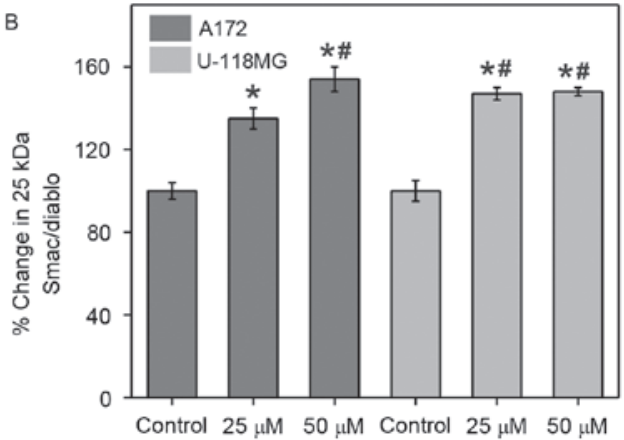

D

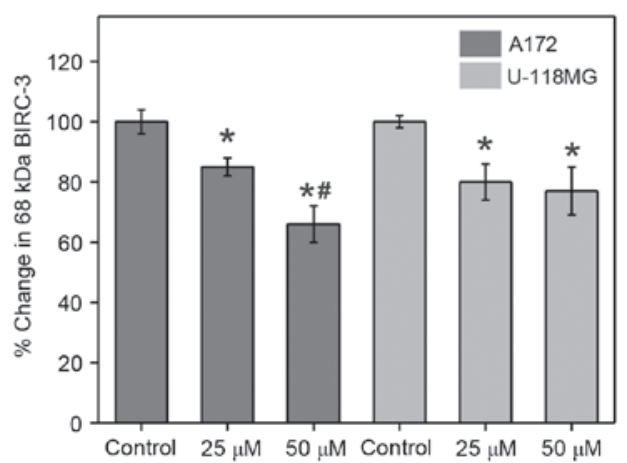

Figure 8. (A) Western blots, and quantified densitometric analysis results demonstrating the expression levels of (B) Smac/Diablo, (C) BIRC-2 and (D) BIRC-3 in $\alpha$-tomatine treated A172 and U-118 MG cell lines. ${ }^{*} \mathrm{P}<0.05,{ }^{* \#} \mathrm{P}<0.01$ vs. control. BIRC, Baculoviral IAP repeat-containing protein.

A

B
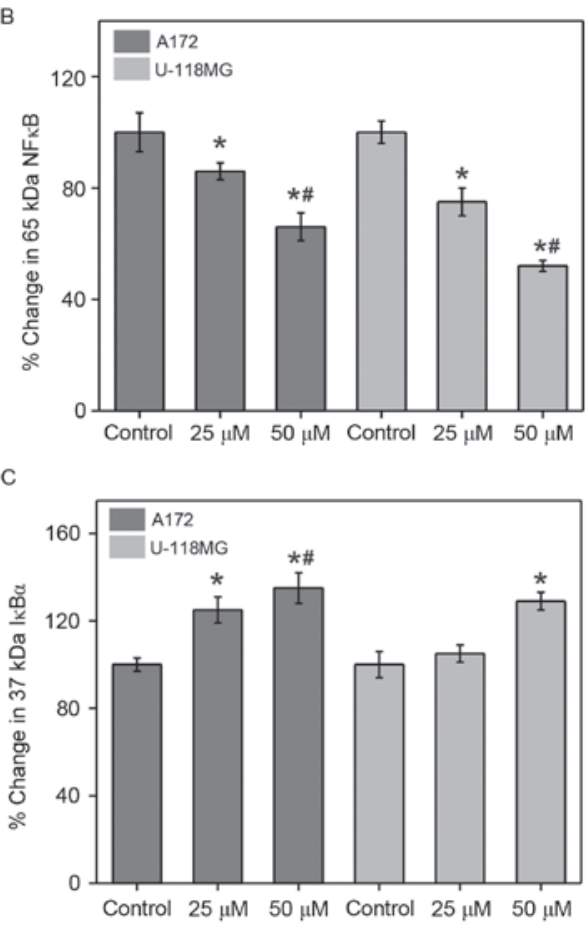

Figure 9. (A) Western blots, and quantified densitometric analysis results demonstrating the expression levels of (B) $N F-\kappa B$ and $(C) I \kappa B \alpha$ in $\alpha$-tomatine-treated A172 and U-118 MG cells. ${ }^{*} \mathrm{P}<0.05,{ }^{* \#} \mathrm{P}<0.01$ vs. control. $\mathrm{NF}-\kappa \mathrm{B}$, nuclear factor- $\kappa \mathrm{B}$; I $\mathrm{IB} \alpha$, inhibitor of $\mathrm{NF}-\kappa \mathrm{B}$. that ER stress can induce caspase-12 activation, which is directly associated with caspase-9 activation $(29,30)$. Furthermore, the present study measured the activities of calpain and caspase- 3 activation, according to previous findings stating that the degradation of $\alpha$-spectrin to 145 and $120 \mathrm{kDa}$ SBDP is responsible for caplain and caspase-3 activation, respectively $(31,32)$. From the results obtained, it was proven that elevated calpain and caspase- 3 levels served a crucial function in $\alpha$-tomatine-triggered apoptosis in A172 and U-118 MG cell lines. A previous relevant report also supported the association of calpain and caspase-3 activation with apoptosis (33).

Furthermore, $\alpha$-tomatine was observed to trigger the activation of caspase- 3 as identified from the $20 \mathrm{kDa}$ fragment of caspase- 3 and ICAD cleavage in the present study. These results demonstrated that $\alpha$-tomatine induced caspase- 3 activation, which is able to cleave ICAD to permit translocation of CAD into the nucleus for caspase-dependent DNA nuclear fragmentation, and this finding is consistent with the observations of a previous study (34).

Caspase-independent apoptosis is known to also be induced by mitochondria upon the release of AIF (35); thus, the present study examined the changes in AIF cytosolic levels to determine the feasibility of caspase-independent apoptosis following $\alpha$-tomatine treatment in the glioblastoma cell lines. The data strongly indicated the enhancement of AIF cytosolic levels after $\alpha$-tomatine treatment, proving that $\alpha$-tomatine induced AIF mitochondrial efflux into the cytosol. This translocation may produce caspase-independent apoptosis and DNA nuclear fragmentation (36). According to the aforementioned results, it can be demonstrated that both caspase-dependent and independent pathways participated 
in the $\alpha$-tomatine-directed apoptosis in A172 and U-118 MG glioblastoma cell lines.

The Smac/Diablo release from mitochondria upon $\alpha$-tomatine treatment was also investigated. Since IAPs, such as BIRC-2 and BIRC-3, can be downregulated by Smac/Diablo pro-apoptotic molecules in the cytosol, the BIRC-2 and BIRC-3 cytosolic levels were investigated. $\alpha$-Tomatine treatment was observed to cause reduction in the expression levels of these two genes, which are considered as feasible oncogenes (37). Thus, this suggests that the apoptosis of $\alpha$-tomatine may be due to the oncoprotein downregulation. In addition, collective results indicated that $\alpha$-tomatine treatment induced apoptosis by elevating Smac/Diablo and reducing IAP levels, as well as by caspase activation.

In cell survival, $\mathrm{NF}-\kappa \mathrm{B}$ activation serves a crucial role (38), and thus, the downregulation of NF- $\kappa \mathrm{B}$ by compounds extracted from plant may be a promising approach for preventing cancer development (39). In the experiments of the present study, $\alpha$-tomatine treatment triggered I $\mathrm{B} \alpha$ elevation and IAP downregulation in the two cell lines, suggesting that other than the apoptosis induction, the mechanisms of $\alpha$-tomatine action include IAP and $\mathrm{NF}-\kappa \mathrm{B}$ inhibition for the prevention of cell survival signals. The $\alpha$-tomatine-induced inhibition of $N F-\kappa B$ was due to its decreased binding with DNA. Furthermore, the apoptosis induction in A172 and U-118 MG by $\alpha$-tomatine treatment was shown to be p53 independent (40).

In conclusion, the present study explored the multiple molecular mechanisms involved in the apoptosis induction following $\alpha$-tomatine treatment in A172 and U-118 MG cell lines. $\alpha$-Tomatine exhibited its proapoptotic potentials at 25 and $50 \mu \mathrm{M}$ levels within the physiological dosage. Xenografted/allografted animal models will be used in our future studies for further confirmation of these findings.

\section{Acknowledgements}

The authors would like to thank The People's Hospital of Zoucheng for providing financial support to perform this study.

\section{References}

1. Eitel K, Wagenknecht B and Weller M: Inhibition of drug-induced DNA fragmentation, but not cell death, of glioma cells by non-caspase protease inhibitors. Cancer Lett 142: 11-16, 1999.

2. Castro MG, Cowen R,Smith-Arica J,Williams J,Ali S, WindeattS, Gonzalez-Nicolini V, Maleniak T and Lowenstein PR: Gene therapy strategies for intracranial tumours: Glioma and pituitary adenomas. Histol Histopathol 15: 1233-1252, 2000.

3. Yang QY, Shen D, Sai K, Jiang XB, Ke C, Zhang XH, Mou YG and Chen ZP: Survival of newly diagnosed malignant glioma patients on combined modality therapy. Zhonghua yi xue za zhi 93: 8-10, 2013 (In Chinese).

4. Takahashi $\mathrm{H}$ and Teramoto A: Trial of targeting therapy against malignant glioma using monoclonal antibody. J Nippon Med Sch 71: 2-3, 2004.

5. Hegi ME, Diserens AC, Gorlia T, Hamou MF, de Tribolet N, Weller M, Kros JM, Hainfellner JA, Mason W, Mariani L, et al: MGMT gene silencing and benefit from temozolomide in glioblastoma. N Engl J Med 352: 997-1003, 2005.

6. Jamal M, Rath BH, Tsang PS, Camphausen K and Tofilon PJ: The brain microenvironment preferentially enhances the radioresistance of CD133(+) glioblastoma stem-like cells. Neoplasia 14: 150-158, 2012.

7. Tan W, Lu J, Huang M, Li Y, Chen M, Wu G, Gong J, Zhong Z, $\mathrm{Xu} \mathrm{Z}$, Dang Y, et al: Anti-cancer natural products isolated from Chinese medicinal herbs. Chin Med 6: 27, 2011.
8. Meiyanto E, Hermawan A and Anindyajati: Natural products for cancer targeted therapy: Citrus flavonoids as potent chemopreventive agents. Asian Pac J Cancer Prev 13: 427-436, 2012.

9. Jeong JB, Seo EW and Jeong HJ: Effect of extracts from pine needle against oxidative DNA damage and apoptosis induced by hydroxyl radical via antioxidant activity. Food Chem Toxicol 47: 2135-2141, 2009

10. Singh BN, Singh BR, Singh RL, Prakash D, Dhakarey R, Upadhyay G and Singh HB, Oxidative DNA damage protective activity, antioxidant and anti-quorum sensing potentials of Moringa oleifera. Food Chem Toxicol 47: 1109-1116, 2009.

11. Blankemeyer JT, White JB, Stringer BK and Friedman M: Effect of alpha-tomatine and tomatidine on membrane potential of frog embryos and active transport of ions in frog skin. Food Chem Toxicol 35: 639-646, 1997.

12. Roddick JG: The steroidal glycoalkaloid $\alpha$-tomatine. Phytochemistry 13: 9-25, 1974.

13. Chiu FL and Lin JK: Tomatidine inhibits iNOS and COX-2 through suppression of NF-kappaB and JNK pathways in LPS-stimulated mouse macrophages. FEBS Lett 582: 2407-2412, 2008.

14. Shih YW, Shieh JM, Wu PF, Lee YC, Chen YZ and Chiang TA: Alpha-tomatine inactivates PI3K/Akt and ERK signaling pathways in human lung adenocarcinoma A549 cells: Effect on metastasis. Food Chem Toxicol 47: 1985-1995, 2009.

15. Friedman $\mathrm{M}$ and Levin CE: alpha-Tomatine content in tomato and tomato products determined by HPLC with pulsed amperometric detection. J Agric Food Chem 43: 1507-1511, 1995.

16. Lee KR, Kozukue N, Han JS, Park JH, Chang EY, Baek EJ, Chang JS and Friedman M: Glycoalkaloids and metabolites inhibit the growth of human colon (HT29) and liver (HepG2) cancer cells. J Agric Food Chem 52: 2832-2839, 2004.

17. Shieh JM, Cheng TH, Shi MD, Wu PF, Chen Y, Ko SC and Shih YW: $\alpha$-Tomatine suppresses invasion and migration of human non-small cell lung cancer NCI-H460 cells through inactivating FAK/PI3K/Akt signaling pathway and reducing binding activity of NF- $\mathrm{BB}$. Cell Biochem Biophys 60: 279-310, 2011.

18. Lee ST, Wong PF, Cheah SC and Mustafa MR: Alpha-tomatine induces apoptosis and inhibits nuclear factor-kappa B activation on human prostatic adenocarcinoma PC-3 cells. PLoS One 6: e18915, 2011.

19. Kúdelová J, Seifrtová M, Suchá L, Tomšík P, Havelek R and Řezáčová M: Alpha-tomatine activates cell cycle checkpoints in the absence of DNA damage in human leukemic MOLT-4 cells. J Appl Biomed 11: 93-103, 2013.

20. Shi MD, Shih YW, Lee YS, Cheng YF and Tsai LY: Suppression of 12-O-tetradecanoylphorbol-13-acetate-induced MCF-7 breast adenocarcinoma cells invasion/migration by $\alpha$-tomatine through activating $\mathrm{PKC} \alpha / \mathrm{ERK} / \mathrm{NF}-\kappa \mathrm{B}-$ dependent MMP-2/MMP-9 expressions. Cell Biochem Biophys 66: 161-174, 2013.

21. Yang YW, Wu CA and Morrow WJ: The apoptotic and necrotic effects of tomatine adjuvant. Vaccine 22: 2316-2327, 2004.

22. Ray SK, Wilford GG, Crosby CV, Hogan EL and Banik NL: Diverse stimuli induce calpain overexpression and apoptosis in C6 glioma cells. Brain Res 829: 18-27, 1999.

23. Ray SK, Karmakar S, Nowak MW and Banik NL: Inhibition of calpain and caspase-3 prevented apoptosis and preserved electrophysiological properties of voltage-gated and ligand-gated ion channels in rat primary cortical neurons exposed to glutamate. Neuroscience 139: 577-595, 2006.

24. Das A, Sribnick EA, Wingrave JM, Del Re AM, Woodward JJ, Appel SH, Banik NL and Ray SK: Calpain activation in apoptosis of ventral spinal cord 4.1 (VSC4.1) motoneurons exposed to glutamate: Calpain inhibition provides functional neuroprotection. J Neurosci Res 81: 551-562, 2005.

25. Grynkiewicz G, Poenie M and Tsien RY: A new generation of $\mathrm{Ca} 2+$ indicators with greatly improved fluorescence properties. J Biol Chem 260: 3440-3450, 1985.

26. Hansen CA, Monck JR and Williamson JR: Measurement of intracellular free calcium to investigate receptor-mediated calcium signaling. Methods Enzymol 191: 691-706, 1990.

27. Sribnick EA, Ray SK and Banik NL: Estrogen prevents glutamate-induced apoptosis in C6 glioma cells by a receptor-mediated mechanism. Neuroscience 137: 197-209, 2006.

28. Sribnick EA, Ray SK, Nowak MW, Li L and Banik NL: 17beta-estradiol attenuates glutamate-induced apoptosis and preserves electrophysiologic function in primary cortical neurons. J Neurosci Res 76: 688-696, 2004. 
29. Rao RV, Castro-Obregon S, Frankowski H, Schuler M, Stoka V, del Rio G, Bredesen DE and Ellerby HM: Coupling endoplasmic reticulum stress to the cell death program. An Apaf-1-independent intrinsic pathway. J Biol Chem 277: 21836-21842, 2002.

30. Morishima N, Nakanishi K, Takenouchi H, Shibata T and Yasuhiko Y: An endoplasmic reticulum stress-specific caspase cascade in apoptosis. Cytochrome c-independent activation of caspase-9 by caspase-12. J Biol Chem 277: 34287-34294, 2002.

31. Nath R, Raser KJ, Stafford D, Hajimohammadreza I, Posner A, Allen H, Talanian RV, Yuen P, Gilbertsen RB and Wang KK Non-erythroid alpha-spectrin breakdown by calpain and interleukin 1 beta-converting-enzyme-like protease(s) in apoptotic cells: Contributory roles of both protease families in neuronal apoptosis. Biochem J 319: 683-690, 1996.

32. Wang KK, Posmantur R, Nath R, McGinnis K, Whitton M, Talanian RV, Glantz SB and Morrow JS: Simultaneous degradation of alphaII- and betaII-spectrin by caspase 3 (CPP32) in apoptotic cells. J Biol Chem 273: 22490-22497, 1998.

33. Neumar RW, Xu YA, Gada H, Guttmann RP and Siman R: Cross-talk between calpain and caspase proteolytic systems during neuronal apoptosis. J Biol Chem 278: 14162-14167, 2003 .
34. Jayanthi S, Deng X, Noailles PA, Ladenheim B and Cadet JL: Methamphetamine induces neuronal apoptosis via cross-talks between endoplasmic reticulum and mitochondria-dependent death cascades. FASEB J 18: 238-251, 2004.

35. Cregan SP, Dawson VL and Slack RS: Role of AIF in caspase-dependent and caspase-independent cell death. Oncogene 23: 2785-2796, 2004.

36. Susin SA, Daugas E, Ravagnan L, Samejima K, Zamzami N, Loeffler M, Costantini P, Ferri KF, Irinopoulou T, Prévost MC, et al: Two distinct pathways leading to nuclear apoptosis. J Exp Med 192: 571-580, 2000.

37. Imoto I, Yang ZQ, Pimkhaokham A, Tsuda H, Shimada Y, Imamura M, Ohki M and Inazawa J: Identification of cIAP1 as a candidate target gene within an amplicon at 11q22 in esophageal squamous cell carcinomas. Cancer Res 61: 6629-6634, 2001.

38. Lee R and Collins T: Nuclear factor-kappaB and cell survival: IAPs call for support. Circ Res 88: 262-264, 2001.

39. Dorai T and Aggarwal BB: Role of chemopreventive agents in cancer therapy. Cancer Lett 215: 129-140, 2004.

40. Fimognari C, Sangiorgi L, Capponcelli S, Nüsse M, Fontanesi S, Berti F, Soddu S, Cantelli-Forti G and Hrelia P: A mutated p53 status did not prevent the induction of apoptosis by sulforaphane, a promising anti-cancer drug. Invest New Drugs 23: 195-203, 2005. 